\title{
Expanding entrepreneurship education ecosystems
}

Article

Accepted Version

Belitski, M. and Heron, K. (2017) Expanding entrepreneurship education ecosystems. Journal of Management Development, 36 (2). pp. 163-177. ISSN 0262-1711 doi:

https://doi.org/10.1108/JMD-06-2016-0121 Available at https://centaur.reading.ac.uk/71061/

It is advisable to refer to the publisher's version if you intend to cite from the work. See Guidance on citing.

Published version at: http://dx.doi.org/10.1108/JMD-06-2016-0121

To link to this article DOI: http://dx.doi.org/10.1108/JMD-06-2016-0121

Publisher: Emerald

All outputs in CentAUR are protected by Intellectual Property Rights law, including copyright law. Copyright and IPR is retained by the creators or other copyright holders. Terms and conditions for use of this material are defined in the End User Agreement.

\section{www.reading.ac.uk/centaur}

\section{CentAUR}

Central Archive at the University of Reading

Reading's research outputs online 


\title{
Expanding Entrepreneurship Education Ecosystems
}

\author{
Maksim Belitski and Keith Heron \\ Henley Business School, University of Reading, Reading, UK
}

\begin{abstract}
Purpose

The creation of start-ups using knowledge provided by universities has been identified as an important source of knowledge spillover and regional economic development. Entrepreneurship ecosystems in education have become the most important and efficient mechanism of business community engagement and knowledge transfer within universityindustry-government framework creating value to society and regional economy.
\end{abstract}

Methodology

This study undertakes in-depth synthesis of eclectic literature on entrepreneurship ecosystems and knowledge spillover of entrepreneurship, examining the critical success factors and enablers of entrepreneurship ecosystems in education.

Findings

This study proposes entrepreneurship education ecosystems as an alternative unit of analysis when it comes to considering the role of university-industry-government collaboration in knowledge commercialisation. We recommend key entrepreneurship education ecosystem enablers for knowledge commercialization and engagement with entrepreneurial communities.

Originality

We propose a framework for the creation of an entrepreneurship education ecosystem as a unit of analysis when considering the role of university-industry-government collaboration. It requires different approaches to teaching, research and business outreach, some of which have not yet been discovered or yet need to be created.

\section{Introduction}

Over the last two decades the entrepreneurship discipline has expanded from the study of entrepreneurs and the economics of entrepreneurship into a much broader subject, incorporating the promotion of entrepreneurial behavioural patterns of business, individuals and institutions, university-industry-government partnership, start-ups and scale-ups, entrepreneurial aspirations and orientation (Lee, 1996; Etzkowitz and Leydesdorff, 2000; Markman et al. 2005; Bonaccorsi et al. 2013). 
Both entrepreneurship and economic literatures have devoted increasing attention to university's contribution to society and economic development more directly, through turning the university into an Entrepreneurial University (Markuerkiaga et al. 2016). What, however, constitutes this Entrepreneurial University? Are all Entrepreneurial Universities composed of the same factors?entrepreneurship education plays in facilitating university-industry and university-industry -government collaborations (Tether and Tajar, 2008) as well as development of institutional framework in regions where universities, students, scientist, entrepreneurs and government benefit from knowledge spillovers. This institutional framework includes universities, regional culture, mobility, formal and informal networks, market size, regulation and forms of knowledge-transfer collaborations, spin-offs and becomes a powerful conduit of knowledge commercialization (Giunta et al. 2016). The reason for greater attention to the role of entrepreneurship education and entrepreneurship ecosystem being that university teaching and research or spin-off (Fetters et al. 2010; Markuerkiaga et al. 2016), produces knowledge spill-overs that might play an important role as facilitators of start-up in regions (Caiazza et al. 2015) and innovation activity for larger spectrum of businesses (Owen-Smith and Powell, 2004; Mueller, 2006).

There has been a strong focus in policy and academia on expanding an entrepreneurship education ecosystem (EEE) which aims to facilitate academic spinoffs, students and scientists employability, improve institutional framework of knowledge commercialization and a process of spin-off creation (Mustar et al. 2006; Caiazza et al. 2014). This requires stakeholders to create stronger communities of scholars and entrepreneurs in regions, contributing to regional and national entrepreneurship ecosystems (Isenberg, 2010; Autio et al. 2014; Audretsch and Belitski, 2016). EEE is seen as a driver of regional economic development (Wright et al. 2006), while entrepreneurship educators, scientists, entrepreneurs and government demand a stronger link between research and commercialization of knowledge (Caiazza et al. 2014).

A key question remains to what extent creation of entrepreneurship ecosystem in education (EEE) could be used as a unit of analysis when researching university-industry-government collaboration? Whether EEE can serve as a conduit of university-industry-government partnership? What EEE enablers should be in place for knowledge to spillover aiming to knowledge commercialisation, poverty reduction and economic growth (Acs et al. 2013; Caiazza et al. 2015)?

While these questions have been central in the debate on EEE and university-industrygovernment collaboration (Lee, 1996; Autio et al. 2014) in entrepreneurship and innovation 
literature (Caiazza et al. 2015; Caiazza, 2016), there is a gap in the literature on the unit of analysis when researching university-industry-government partnership and key enablers of EEE, aiming to increase knowledge spillover of entrepreneurship and transfer of knowledge from university to market (Audretsch et al. 2006, 2012; Audretsch and Belitski, 2013; Caiazza and Volpe, 2016).

The present study is undertaken to fill part of this void building on entrepreneurship ecosystem and knowledge spillover of entrepreneurship literatures, (Lee, 1996, Audretsch et al. 2006, 2012; Caiazza et. al. 2014; Giunta et al. 2016).

We start our contribution to entrepreneurship literature by conducting systematic literature review of EEE and university-industry-government partnership. Building on Markman et al. (2005), Fetters et al. (2010) and Caiazza et al. (2014, 2015) we employ a systems-based approach and recognise the integrated and concurrent nature of EEE and its pillars. Prior literature suggests that we need a different unit of analysis when it comes to considering the role of university-industry-government partnerships in knowledge commercialisation.

Building on extent literature on entrepreneurship ecosystems (Autio et al. 2014; Audretsch and Belitski, 2016), entrepreneurship education (Neck and Greene, 2011; Neck, Greene and Brush, 2014) and university-industry-government collaboration (Markman et al. 2005; Giunta et al. 2016).

This study makes three contributions to entrepreneurship and innovation literatures (Szerb et al. 2013; Autio et al. 2014; Caiazza and Volpe, 2016). First, it offers an in-depth synthesis of eclectic literature examining the critical success factors of EEE. Second, we examine and discuss critical pillars (enablers) of EEE which serve as a conduit of knowledge commercialisation: engagement of all stakeholders within university-industry-government partnership, creating an entrepreneurship culture in universities, formal and informal infrastructure and networks; Technology Transfer Offices (TTOs) and centres for entrepreneurship as a conduit for knowledge spillover. Third, we contend that the systematic review presented also makes an important practical contribution by connecting university, industry and government within a one unit of analysis - entrepreneurship ecosystem of education. Building on systematic literature review we further develop strategies in order to increase entrepreneurial education performance and knowledge commercialization.

The remainder of the paper is organized as follows. Section 2 introduces methodology of systemic literature review on entrepreneurship ecosystems of education. Section 3 provides a definition and discusses what constitutes entrepreneurial ecosystem in education. Section 4 
reports advances on pillars of EEE such as research commercialization and entrepreneurial education, while Section 5 provides an overview and demonstrates the role of technology transfer offices (TTOs) and entrepreneurship centres as conduits of knowledge spillover for entrepreneurship. Section 6 describes approaches to best practice of entrepreneurship education at a heart of EEE. Section 7 concludes, describes contributions and outlines future research.

\section{Methodology}

Systematic review arguably provides the most reliable and efficient method of identifying and evaluating a sizeable amount of literature (Hart, 1998; Mulrow, 1994). The difference between a traditional narrative and a systematic literature review lies in the process of gathering and analyzing information (Tranfield et al. 2003). In a narrative review, the implicit bias of the researcher plays a decisive role in the selection of publications, while in a systematic review selection is guided by clear rules. The other significant difference lies in the transparency of the process and analysis. Narrative reviews offer a descriptive account of contributions made by researchers, while a systematic review uses a priori design to analyze and provide a critical assessment (Hart, 1998). In short, a systematic review, by making explicit the values and the assumptions deployed in the evaluation of the literature, minimizes researcher bias. Furthermore, by leaving a clear audit trail it offers the possibility of replicating the review, closely aligning the systematic review with the practice of scientific enquiry.

For the purpose of this study we broadly followed the process outlined by Hart (1998). There are many similarities between this process and that outlined by Tranfield et al. (2003). We used a four-stage process with several steps in each stage. In the first stage we developed the need, scope and aim of the review. The aim and research question guided the succeeding stages. In the second stage we developed our search strings and a set of coarse-grained criteria designed to establish publications' eligibility for inclusion in the long list of potential review publications. We developed our search terms and strings by identifying several highly cited publications and analyzing author-supplied keywords coupled with extensive discussion with five experts in the field (see Table 1 for the search terms). Next we defined our coarse 
eligibility criteria - subject areas, type of output and the reviews time line (see Table 2). These coarse criteria enabled us to identify a long list of potential review publications.

Table 1. Search terms

\begin{tabular}{|l|l|l|}
\hline \multicolumn{1}{|c|}{ First search string } & \multicolumn{1}{c|}{$\begin{array}{c}\text { Conditional } \\
\text { proposition }\end{array}$} & \multicolumn{1}{|c|}{ Second search string } \\
\hline Entrepreneurship Ecosystem & and & Definition \\
Entrepreneurship Ecosystem & and & Key success factors \\
Entrepreneurship Ecosystem & and & University-Industry collaboration \\
Entrepreneurship Ecosystem & and & University-Industry-government partnership \\
Entrepreneurship Ecosystem & and & Stakeholders \\
Entrepreneurship Ecosystem & and & Education \\
Entrepreneurship Ecosystem & and & Entrepreneurship education \\
Entrepreneurship Ecosystem & and & Institutions \\
Entrepreneurship Ecosystem & and & Innovation \\
Entrepreneurship Ecosystem & and & Experiential learning \\
\hline
\end{tabular}

We restricted our search in terms of subject area, to entrepreneurship, general management, strategy, innovation, education, economics of science, industrial economics. These subjects constitute the key areas of the entrepreneurship ecosystem in education field and address a broad range of problems related to entrepreneurial education and institutionalization of university-industry collaboration (Caiazza et al. 2014; Neck et al. 2014; Alto and Farny, 2016). Journals dedicated to publication in these areas are most likely to publish entrepreneurship ecosystem and university-industrial partnerships-related research. Furthermore, we restricted our search to journals with a Social Sciences Citation Index (SSCI). Following Tranfield et al. (2003) we did not include conference proceedings, unpublished studies and publications appearing on the internet beyond the practitioners' journals. Journals that aim to publish authoritative reviews in the entrepreneurship and general management disciplines encourage contributors to draw almost exclusively on rigorous empirical research (Armstrong and Wilkinson, 2007), which is more likely to be found in peer-reviewed journals. Therefore, on balance, we concluded that it was better to restrict our review to peer-reviewed articles with an SSCI. 
Furthermore, we limited our search to between 1996 and 2016 with a few exceptions of studies on the several educational techniques and engagement exercised in entrepreneurship education relevant to practical recommendations. The period covered by the review $2000-$ 2016 is of critical importance. The period overlaps with the period where spin-offs and increase in networking between EEE players became prominent. We searched four electronic databases - EBSCO, ABI Inform, Web of Science and Science Direct - using the search strings in Table 1. Although the process yielded 1,472 publications, only 224 publications met our coarse long-listing criteria and SSCI criteria.

The third stage involved developing fined-grained criteria such as definitions of key terms, unit of analysis, to include or exclude the long-listed papers from our final analysis. As a first step we defined the three terms critical to inclusion/exclusion decisions - entrepreneurship ecosystem, entrepreneurship education, and university-industry partnership research. We offer a definition of entrepreneurship ecosystem in the next section.

In the fourth stage, we applied the fine-grained criteria described to identify the publications to be reviewed. One researcher examined all the long-listed articles, while other researcher examined a batch of articles. The choices were compared. Disagreements were identified and resolved following detailed discussions, always referring to the pre-defined fine-grained inclusion/exclusion criteria in Table 2 (Tranfield et al. 2003). Overall each publication was judged against the fine-grained criteria by two researchers. As a consequence, 80 papers were selected for review - with 37 papers finally included in this study in addition to publications earlier 2000s which enter this study for discussion reasons and book chapters. The list of journals we used in our search and the number of papers from each journal included in this review is provided in Appendix A.

Table 2. Coarse- and fine-grained inclusion/exclusion criteria

\begin{tabular}{|c|c|c|c|}
\hline & $\begin{array}{l}\text { Decision } \\
\text { variables }\end{array}$ & Inclusion criteria & Exclusion criteria \\
\hline 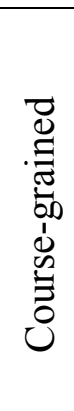 & Subject areas & $\begin{array}{l}\text { entrepreneurship, general } \\
\text { management, strategy, } \\
\text { innovation, education, } \\
\text { economics of science, } \\
\text { industrial economics }\end{array}$ & $\begin{array}{l}\text { Finance, entrepreneurship } \\
\text { aspirations, economics, } \\
\text { public sector, ethics, } \\
\text { corporate social } \\
\text { responsibility, citations, } \\
\text { specific sector but not }\end{array}$ \\
\hline
\end{tabular}




\begin{tabular}{|c|c|c|c|}
\hline & & & $\begin{array}{l}\text { education (e.g. IT, recycling, } \\
\text { machinery, hospitality, etc.). }\end{array}$ \\
\hline & Publication type & $\begin{array}{l}\text { Peer-refereed journal with an } \\
\text { SSCI. }\end{array}$ & $\begin{array}{l}\text { Peer-refereed journals } \\
\text { without an SSCI, conference } \\
\text { papers, all internet } \\
\text { publications except of policy } \\
\text { relevant resources such as } \\
\text { Business Innovation and } \\
\text { Skills UK, Times Higher } \\
\text { Education and Financial } \\
\text { Times publications. }\end{array}$ \\
\hline & $\begin{array}{l}\text { Period of } \\
\text { coverage }\end{array}$ & 1996 to 2016. & $\begin{array}{l}\text { Prior to } 2000 \text { (exception are } \\
\text { papers not included in a } \\
\text { review and used for best } \\
\text { practice examples e.g. } \\
\text { Matheson (2015) on MIT } \\
\text { spin-offs). }\end{array}$ \\
\hline 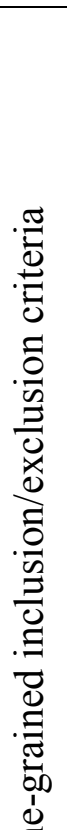 & $\begin{array}{l}\text { Entrepreneurship } \\
\text { Ecosystem }\end{array}$ & $\begin{array}{l}\text { Network of organizations, } \\
\text { entrepreneurs, universities and } \\
\text { government that co-evolve } \\
\text { their capabilities and roles and } \\
\text { align their investments and } \\
\text { ideas so as to create additional } \\
\text { value within six important } \\
\text { areas: finance, culture, } \\
\text { infrastructure, human capital, } \\
\text { markets and regulation } \\
\text { (adapted from Isenberg, 2010). }\end{array}$ & $\begin{array}{l}\text { Articles where authors did } \\
\text { not provide an explicit or } \\
\text { implicit definition of } \\
\text { entrepreneurship ecosystem. } \\
\text { Articles related to bio- } \\
\text { ecosystems with biological } \\
\text { community of interacting } \\
\text { organisms. } \\
\text { Articles that used ecosystem } \\
\text { to describe one entity or one } \\
\text { enterprise or unit. }\end{array}$ \\
\hline & $\begin{array}{l}\text { University- } \\
\text { Industry- }\end{array}$ & $\begin{array}{l}\text { Collaboration between a } \\
\text { university, industry and } \\
\text { government on knowledge }\end{array}$ & $\begin{array}{l}\text { Systems that do not deal with } \\
\text { inter-firm collaboration, } \\
\text { networking or dynamic }\end{array}$ \\
\hline
\end{tabular}




\begin{tabular}{|l|l|l|l|}
\hline $\begin{array}{l}\text { government } \\
\text { partnership }\end{array}$ & $\begin{array}{l}\text { creation, dissemination and } \\
\text { transfer, technology creation } \\
\text { and commercialization of } \\
\text { knowledge by entrepreneurs. } \\
\text { - }\end{array}$ & $\begin{array}{l}\text { organizational environment } \\
\text { were excluded. }\end{array}$ \\
\hline Type of research & $\begin{array}{l}\text { Quantitative and qualitative } \\
\text { empirical research. }\end{array}$ & $\begin{array}{l}\text { Opinion, anecdotal, } \\
\text { conceptual, theoretical. }\end{array}$ \\
\hline Unit of analysis & $\begin{array}{l}\text { Stakeholder unit of assessment } \\
\text { (university, organization, } \\
\text { entrepreneur, government). }\end{array}$ & $\begin{array}{l}\text { Falling outside our definition } \\
\text { of entrepreneurship } \\
\text { ecosystem stakeholder, that } \\
\text { is to say, teams, strategic } \\
\text { business units, industry as a } \\
\text { whole. }\end{array}$ \\
\hline $\begin{array}{l}\text { Sectors } \\
\text { coverage }\end{array}$ & All sectors. & None. \\
\hline Geographic & All regions. & None. \\
\hline
\end{tabular}

The fifth and final stage was concerned with data extraction. Both Hart (1998) and Tranfield et al. (2003) suggest that reliable and valid reviews utilize standardized pre-determined dimensions for abstracting data from articles (authors team, major findings, strengths (success factors), weaknesses (challenges) and tools used. To map the effort of the published empirical research we took our lead from the knowledge spillover of entrepreneurship theory (Audretsch et al. 2006, 2012; Acs et. al. 2013) and innovation ecosystem theory (Autio et al. 2014) to codify the reviewed literature and offer answers to our research questions. The motivation for this comes from the essence of entrepreneurship ecosystem in education discussed in the next section.

\section{What constitutes Entrepreneurship Ecosystem in Education?}

Despite the growing interest in commercialization of knowledge, there is no perfect agreement on the nature of EEE and what role it play in regional economic development, 
knowledge and university-industry-government partnership (Clarysse and Moray, 2004; Azagra-Caro et al. 2006; Caiazza et al. 2015). There is also no agreement on conditions that enable the creation of instruments and mechanisms internally at the university level to support entrepreneurial activity and innovation diffusion within EEE (Pirnay et al. 2003; Algieri et al. 2013). Factors affecting diffusion of knowledge and innovation were widely discussed in Caiazza Volpe (2016) which clarified the role of innovator, adopters and intermediaries and evidences actions that policy-makers can implement to facilitate knowledge transfer and support innovation, including cross-country aspect of it (Caiazza, 2016).

Understanding of the role that the culture of entrepreneurialism and entrepreneurship education can play as a factor of the entrepreneurial ecosystem was first discussed in Isenberg (2010) and extended by Autio et al. (2014) and . Although the term 'entrepreneurship ecosystem' has been increasingly used in the innovation and entrepreneurship literatures (Alto and Farny, 2016; Audretsch and Belitski, 2016), it evolves with changes in entrepreneurship ecosystem stakeholders and greater emphasis on knowledge commercialisation activity. It also geographically limits stakeholders' interests and collaboration links (Acs et al. 2014). Whether new companies emerge not only depends on individual or group is talented, but also on a set of external conditions such as other private and public players - the entrepreneurial ecosystem stakeholders (Szerb et al. 2013). Entrepreneurial ecosystem in education (EEE) emerges as a complex system of multi-level collaborative links between major stakeholders (e.g. university, business, local government, students, researchers, etc) with several related elements that either promote or hinder knowledge transfer and commercialisation by industry and university (Wright, 2006). We also use the definition by Autio et al. (2014) of an entrepreneurship ecosystem as a dynamic, institutionally embedded interaction between university and entrepreneurs characterized by entrepreneurial attitudes, abilities and aspirations, which drive the allocation of resources through the creation of new business (spin-offs) or new technology (university-industry partnership). EEE builds on economic geography and proximity (Lee, 1996; Giunta et al. 2016), regional systems of innovation and entrepreneurship literature (Szerb et al. 2013; Autio et al. 2014) and knowledge spillover of entrepreneurship literature (Audretsch et al. 2006; 2012; Acs et al. 2013).

An important addition to the Isenberg's (2010) entrepreneurship ecosystem model is EEE model of the relationship between each stakeholder of the entrepreneurship ecosystem where 
university-industry-government partnership plays the leading role in knowledge commercialisation (Azagra-Caroet et al. 2006).

The Isenberg's model (2010) elaborates important pillars for building an efficient entrepreneurial ecosystem (finance, culture, infrastructure, human capital, market demand and regulation) as well as including systemic conditions, such as networks, collaboration and leadership.

The notion of EEE overlaps with the concept of the 'entrepreneurial university', since EEE introduces an ambitious agenda for universities, entrepreneurs, government and industry that proactively engage with their immediate business environment within their local and national economies. The so-called 'triple-helix' model proposed by Etzkowitz and Leydesdorff (2000) posits the university at the centre of university-industry-government relationships and describes the prominent role universities can play for innovation and economic development in a Knowledge Society. MIT, the global exemplar, has created 30,200 businesses, employing 4.6 million and generating nearly $\$ 2$ trillion in annual revenues (Matheson, 2015).

Cambridge, the leading entrepreneurial HEI in the UK, has seen 1,400 spin-outs, employing 40,000. For example in the UK, both the National Center for Entrepreneurship in Education (NCEE) and the Institute for Small Business and Entrepreneurship (ISBE) have provided a range of case studies and research papers on the subject, and the Times Higher has championed the Entrepreneurial University through its annual awards for several years. Although, the number of EEE has been growing, graduates and scientists remain the major force of knowledge transfer, with much of this knowledge transfer occurring in a local proximity and within entrepreneurial communities linked to the university (Acosta et al. 2011; Bonaccorsi et al. 2013; Giunta et al. 2016). The variety of university specializations with scientists and students involved influences the emergence of knowledge spillovers within industrial clusters applied to technological knowledge fostering the creation of new firms as a start-ups, spin-offs and scale-ups. An academic spin-off (Azagra-Caro et al. 2006; Fini et al. 2011; Markuerkiaga et al. 2016) is intended as a new high-tech venture promoted and launched by an academic researcher that aims to exploit the results of previous research projects on academic spin-offs and provide insights on creating an entrepreneurial ecosystem supporting creation of academic spin-offs in regions.

EEE thus aims to have at least one academic researcher who owns or has access to new technology and is able to establish university-industry-government partnership in order to launch new business venture as a form of new technology commercialisation (Audretsch et 
al. 2006). In addition, engagement of local entrepreneurial communities in a profit-oriented new venture is crucial for organically integrating the EEE into a broader regional ecosystem of entrepreneurship (Szerb et al. 2013). Spin-offs and new venture participants in the ecosystem are students, professors, interns, entrepreneurs, local policy-makers and industry representatives, and anyone who is able to engage and facilitate monetization of new technology through university-industry-government partnership. Commercialisation usually takes a form of a spin-off or intrapreneurship in the incumbent firm (Audretsch et al. 2005; 2012). An important challenge for researchers, government and industry while supporting EEE remains an increase of universities' ability to generate spin-offs and their survival (Caiazza et al. 2014, 2015). Section 4 will define and explain major pillars of EEE.

\section{Knowledge commercialization and entrepreneurial education: evidence from the UK}

The literature review evidenced that commercialization of university-based knowledge does not happen automatically. For example, several US states with large and prize-awarded universities demonstrate low entrepreneurship activity (Chinni and Gimpel, 2011), despite the high levels of human capital, creativity and knowledge discovery. The University's immediate business environment may not be able to help should the entrepreneurship educational be weak and prospective stakeholders be not interested or not enough motivated to engage with the university. This includes researchers, entrepreneurs and policy-makers who are often excluded from university-industry-government partnership (Giunta et al. 2016). A university may be located in one of the most entrepreneurial regions in Europe, as University of Reading in Reading or University of Sussex in Brighton and access extensive support to spin-offs and commercialization of tacit knowledge. Although many of specialized businesses may become tenants in the University campus or business parks, if collaboration does not take place with the universities, scientists and entrepreneurs are excluded from knowledge transfer and knowledge remains uncommercialized (Acs et al. 2013; Audretsch and Belitski, 2013; Caiazza and Volpe, 2016).

There is growing awareness of the importance of research commercialization and entrepreneurial education as a major missing pillar for EEE (Fini et al. 2011; Audretsch et al. 2012). We found that in both developed and developing countries, universities have embarked on prioritising entrepreneurialism and students' employability as a key metric of 
EEE with major focus on greater visibility and development of entrepreneurial skills. The system of Higher Education funding in the UK, for example, has undergone major reforms and changes in the last few years (BIS, 2014) aiming to increase employability along with facilitating knowledge transfer between university and industry under government support. In the UK, graduate employability is becoming a key factor influencing subject and university choice. As foreshadowed in the recently published green paper 'Fulfilling our Potential', the UK Government intends to further reinforce employability as a key metric' (BIS, 2015). In addition to development of employability and entrepreneurial skills in students and faculty, a stronger EEE needs resources allocated for research funding (Mason and Brown, 2014) which has also seen significant changes in the UK, most notably through the increased importance of 'impact' funding and technology co-creation between university and industry through research councils, such as Higher Education Funding Council for England, Economic and Social Research Consortium, Local Enterprise Partnerships (LEPs), Knowledge Transfer Partnership schemes and the European Union 2020 Horizon programme. Success in research translation to industry, and specifically in the commercialisation of university research, is of ever greater importance (BIS, 2015). This policy is supported by scientific evidence which demonstrates that the world's best institutions at creating impactful innovation are also the leading institutions where academics attract private funding and create spin-offs (Caiazza and Audretsch 2013, 2016; Ewalt, 2015; Times Higher Education, 2016).

Investments in research translation initiatives and in the regional economic development in the UK regions welcome initial steps in creating the Entrepreneurial Universities and Universities' entrepreneurial ecosystem, but these investments need to be incorporated into a broader vision for entrepreneurship at the micro-level within centers for entrepreneurship, Technology transfer (TT) offices and University management. The objective of the EEE is to integrate the growing knowledge exchange with the industry under support of government and research translation initiatives into improving and expanding entrepreneurship education and spin-offs that exploit regional advantages inspired by Etzkowitz and Leydesdorff (2000) university-industry-government collaboration model improving diffusion of knowledge and innovation (Caiazza, 2016).

\section{Technology Transfer Offices (TTO) and entrepreneurship centres}


In entrepreneurship ecosystem literature the role of the TTO and entrepreneurship centres in spin-offs and knowledge commercialization is sparse. It remains unclear which TTOs' structures and engagement strategies with business are most conducive to knowledge commercialization and spin-offs. It is not surprising as distilling factors may take long, given various TTOs' structures and strategies are highly correlated with each other when attempting to build a strong university-industry-government partnership (Markman et al. 2005). Our literature review reveals a complex set of relationships between TTO structure and strategies and the role that centres for entrepreneurship also known as centers for entrepreneurial excellence have played in knowledge commercialisation, public and industry policy (Markman et al. 2005).

In highly competitive environment Centres for entrepreneurship foster the formation of entrepreneurial mind-set within the ecosystem, including university based EEE when students, scientists and business feel free to experiment with knowledge, take time to develop products, get mentor support when product commercialization process.

It becomes clear that success of EEE in university settings is often determined by how well technology is transferred from the labs to their startup firms. University technology transfer offices function as "technology intermediaries" in fulfilling this role expanding teaching, research and extra- curricular activities quickly and successfully. In addition to TTOs, Centers for Entrepreneurship enhance university-industry-government collaboration by promoting entrepreneurial ideas and outreaching local business communities in a region. Faculty and students in the university acquire strong practical applications and co-curricular activities with support of TTOs and Centres for Entrepreneurship can start a business (Markuerkiaga et al. 2016). Former have remained a central component of the university based entrepreneurship ecosystems, focused both on the co-curriculum activities with business community development across and beyond university campus. Business outreach is achieved through promotion of knowledge exchange activities where entrepreneurs, scientists and students participate, such as entrepreneurship days, events, engagement with TTOs, workshops for business (Lockett et al. 2003), finally, providing access to new funding opportunities to students and scientists (e.g. equity and reward-based crowdfunding, angel investments).

TTOs structures and strategies require to bridge the gap between university research and industrial testing of new technologies and business model as emphasized in Caiazza and Audretsch (2013), however a lack of funding and product developmental support remains a 
main challenge while spin-offs and knowledge commercialisation (Caiazza and Volpe, 2016). We therefore draw scholars and policy-makers attention to the importance of creation of an ecosystem of entrepreneurship in education where venture initiation is supported by industry and private investors. Products and technologies which are developed outside the EEE are at risk to remain small and never spin-off. In their study Caiazza and Audretsch (2013) highlighted an importance of idiosyncratic approach to understanding and classifying spinoffs across internal, relational and external dimensions and drawing on various theoretical perspectives to explicitly distinguish important support required by the ecosystem for spin-off growth.

EEE aim to develop collaborative links between three major stakeholders: government, university and entrepreneurs where universities' TTOs and centers of entrepreneurship work together and outreach local business community and policy-makers. For example, many spinoffs benefit from their collaboration with university and government, including indirect (e.g. students' placement, internships, workshops, etc.) and direct support (e.g. funding from government consortiums, Research Councils, LEPs, European Commission and consultancy).

\section{Entrepreneurship Education}

Entrepreneurship education is at the heart of EEE. It is seen to be a strategic blend of consulting, education, coaching and research with complimentary knowledge created within an entrepreneurship ecosystem which could be further monetised. The performance enhancement in entrepreneurship education is directly related to better understanding market opportunities and hence spillovers knowledge for entrepreneurship (Audretsch et al. 2006). Much of performance enhancement could be learnt from the most famous business schools, such as Bocconi in Milan, MIT, Harvard and Boston College in Boston, Berkley in San Francisco, George Washington University in Washington DC and Indiana University in Bloomington to name a few by building on the significant foundation that has already been laid by those schools should be used.

Following the existing best practices it is important not just embrace entrepreneurship education on the surface, but to create a highly attractive campus experience to all stakeholders of EEE, including local policy-makers, entrepreneurs and would-be entrepreneurs, students, scientists and business. Building on systematic literature review in 
section 2 and analysis in section 3, we specify the following strategies discussed in order to increase entrepreneurial education performance and knowledge commercialization rate. First, expanding the footprint of entrepreneurial education across the university. We suggest that it be made mandatory that every single undergraduate programme at the university have an entrepreneurship stream made available. This could be through increasing access to the existing university-wide general modules in entrepreneurship or by creating more subjectspecific modules to be included as core within established programmes (e.g. Entrepreneurial Management for Food scientists, Entrepreneurial Management for Creative Artists, Enterprise education for Biosciences). This can be done through the introduction of theorypractice mixed learning in the respective departments. As in Gibb (2002: 258): "perhaps the foremost [purpose of raising awareness about entrepreneurship] is to move the focus of entrepreneurship teaching and research away from the narrow business orientation towards the notion of the development of the enterprising person in a wide range of contexts and the design of organizations of all kinds to facilitate appropriate levels of 'effective' entrepreneurial behaviour".

Second, is action learning and scientists' engagement in entrepreneurial modules. Action learning involves challenging assumptions and finding problems to solutions. Deeper learning occurs when conflict is encountered which requires specific environmental factors to be deeply considered and their impact upon theory questioned and analysed. This occurs not only in an educational learning context but also in an organisational learning context (Argyris and Schon, 1978).

Actioned-based approach introduced by Babson College (Gibb, 2002; Neck and Greene, 2011) suggests that teaching should provide the experience of entrepreneurship and move from being overwhelmingly lecture-based to increasingly practice-based with a greater engagement of scientists, where students pursue projects jointly with scientists on campus or in incumbent forms or in spin-offs contributing to spin-off legacy, or in consultancy projects with start-up entrepreneurs. Evidence of the advantages of active learning is in "Entrepreneurship Theory and Action" approach, where students follow major 4 principles of learning: Action trumps everything, start with your means, build partnerships, do not be the best-be the only. Since 1982 this method has helped thousands of entrepreneurial educators and scientists to look different at the role of entrepreneurial education and engage in Action rather than theorization of knowledge (Neck and Greene, 2011; Neck, Greene and Brush, 2014). Gibb (1997: 19) reports that 'entrepreneurs...learn by copying, by experiment...by 
problem solving and opportunity taking; and from mistakes' with learning involves 'reflection, theorizing, experiencing and action' (Taylor and Thorpe, 2004: 204). Third, to practise theory-based capability development is important. As Fiet (2001a) proposed that in order to assist students to become skilled in theory-based competencies, there is a need to develop new approaches to practise theory-based skills. Such approaches as Fiet (2001b) posits "should attempt to address the problem of anecdotal teaching, which is limited because the type of situation an entrepreneur is likely to encounter will probably not fit the type described in the classroom, nor will studying entrepreneurial profiles from case studies inspire potential entrepreneurs' unless they fit the same profile".

Pittaway and Cope (2007) suggest a suitable situation for developing entrepreneurial capabilities, for which they have empirical evidence, is in the planning and activation of new venture enterprise courses that build on the observation that 'people learn from experience where they are involved in problem solving. Development of entrepreneurial capabilities and mind-set should improve the campus-based experience of students and businesses, but also engage would-be entrepreneurs with scientists and business to advance and promote further knowledge commercialisation.

Fourth, it is providing infrastructure for engagement with entrepreneurial community and policy-makers. Opening up the centers for entrepreneurship network and events to local entrepreneurship community and inviting policy-makers as keynote speakers will facilitate the knowledge exchange and transition of research initiatives from the university to incumbents and entrepreneurs. This is likely to further improve research commercialization outcomes and matches between scientists, business and government. These activities reflect the extent to which knowledge transfer and business engagement is supported by university (Fernald, Solomon and El Tarabishy, 2005) and requires significant allocation of resources to get scientists engaged across the university departments.

Several authors have noted the importance of providing learning opportunities for entrepreneurs on campus. In so doing, entrepreneurs are able to use students and scientists to elicit feedback, whilst students and scientists can learn vicariously (Bandura, 1986) from close observation of the entrepreneur.

Fifth, it is providing facilities for networking with students and alumni. The traditional campus is a place that is busy during term time and deserted otherwise, a place students visit for three years and then return once a year for reunions. This tradition is perishing in European and the UK universities, while still remain strong in the US top colleges. An EEE 
requires finding a space and building a network channel for ongoing engagement with businesses, scientists and alumni. In particular, along with building the number of incubators on campus and investment should be put in both development of formal infrastructure (facilities, amenities, trees, office equipment, water and electricity supply), but also informal infrastructure and network capacity building with alumni (Hayter, 2013). An impressive example is "Entrepreneurship Tuesdays" in the Engineering department at Cambridge University organized by the Center for Entrepreneurship Learning. .

Networks are important for both knowledge and ideas exchange as well as for financing entrepreneurship start-ups and academic spin-offs. Financing for entrepreneurship activity could be raised from various networks, including internal university entrepreneurship community for product commercialization resources, external entrepreneurship community, sponsorships from key university stakeholders such as angel investors and VCs and from donations from university alumni, government funding grants. Many universities have gone the route of alumni clubs and networking but few managed to use them for product validation experiments, external sources of fundraising, public outreach, knowledge exchange, job placements and other

All five approaches taken together will contribute to formation of far-reaching entrepreneurship ecosystem in education. Creating an EEE aims at easing a process of market entry, technology testing and engaging with external stakeholders (Times Higher Education, 2015). Creating an efficient entrepreneurship ecosystem in education is about changing its mode of delivery entrepreneurship education to a more practice-based approach, and enabling various forms of knowledge commercialisation e.g. start-ups, scale-ups and spin-offs, improvements in the amenities, educational infrastructure and networks with alumni and entrepreneurship society, expanding entrepreneurship education across most of departments, engaging local and national policy-makers who aim to facilitate knowledge transfer and regional economic development (Caiazza et al. 2015).

\section{Conclusion}

In recognizing that entrepreneurship ecosystem in education (EEE) literature remains undertheorized and fragmented (Markman et al. 2005; Fetters et al. 2010; Audretsch et al. 2012; Caiazza et al. 2015), this study aimed at a systematic review of EEE literature and proposes important pillars and foundations of EEE. Building on entrepreneurship ecosystem 
theory (Isenberg, 2010; Autio et al. 2014), applied to foundations of the entrepreneurship ecosystem (Audretsch and Belitski, 2016) and knowledge spillover of entrepreneurship literature (Audretsch et al. 2006) applied to spin-offs (Caiazza et al. 2014, 2015; Caiazza, 2016), researchers have revised and redefined the understanding of ecosystem of entrepreneurship in education pillars and enablers, emphasizing the importance of EEE to embed university-industry-government collaboration (Markman et al. 2005; Azagra-Caro et al. 2006).

Based on a systematic analysis of an extensive set of relevant publications, this study makes three specific contributions.

First, we make a contribution to the entrepreneurship ecosystem theory and the knowledge spillover of entrepreneurship literature by offering an in-depth synthesis of eclectic literature examining the critical success factors of EEE. Our review reveals the variety of conceptualizations associated with ecosystem of entrepreneurship and university-industry collaboration as important criteria for EEE commercialization of knowledge. As the university-industry-government collaboration is an important boundary condition for EEE performance, this literature remains undertheorized, fragmented and inconclusive, when addressing university as a unit of assessment. Our major theoretical contribution is in explaining to what extent creation of EEE can serve as a conduit of knowledge commercialisation by scientists and entrepreneurs within university-industry-government collaboration framework. We propose EEE should be considered as a unit of analysis when researching university-industry-government collaboration.

Second, our literature systematic review enables us to determine four important pillars (enablers) of EEE: engagement of all stakeholders within university-industry-government partnership framework, creating an entrepreneurship culture in universities through entrepreneurship education and business outreach, creation of formal and informal infrastructure and networks; TTOs and centres for entrepreneurship to become conduits for innovation diffusion (Caiazza and Volpe, 2016). These pillars do not depend on the location or size of university, business community or a region and go beyond identifying entrepreneurial opportunities to tacit knowledge exchange and commercialization by scientists and entrepreneurs (Fernald et al. 2005).

Third, our practical contribution is emphasizing the role of EEE and the expansion entrepreneurship education strategies which could be extended for both developed and developing countries. Ecosystems with stakeholders and developed infrastructure, 
entrepreneurial education being action-based, entrepreneurship culture, university-industrygovernment partnership, regulation and institutions for knowledge commercialisation are likely to be more resilient and achieve higher efficiency (Etzkowitz and Leydesdorff, 2000; Neck et al. 2014).

Future research should extend our understanding of the role of entrepreneurial education in academic spin-off (Fini et al. 2011), employability and commercialization of knowledge. Building on the best entrepreneurship education practices in section 6 future research may wish to explore the leading EEE models in Europe and the United States aiming to synthesize the assumptions, enablers and mechanisms available to stakeholders within the EEE to further develop and facilitate knowledge spillover of entrepreneurship in universities. When discussing strategies of entrepreneurship education more attention should be paid to stakeholders' connectivity and embeddedness within university-industry-government collaboration framework. We posit on the importance to include all stakeholders in the discussion on pillars and efficient criteria of entrepreneurship ecosystem in education, and in particular business communities, policy-makers, spin-offs and scientists. More research on resources to support EEE is required, including various types of entrepreneurial finance (e.g. social and networks, crowdfunding, VCs, private-public partnerships).

More research on entrepreneurship education delivery methods with focus on development of entrepreneurial culture and skills, new approaches to entrepreneurship education (Neck and Greene, 2011) and the importance of providing learning opportunities for entrepreneurs on campus. Future research will require an understanding of benefits in learning vicariously (Bandura, 1986) from close observation of the entrepreneur by scientists. The role of stakeholders in the EEE could be explored from the prospective of knowledge sharing, resource-pulling, entrepreneurial insights and experience formation, change management in schools and universities on greater business engagement.

\section{References}

Acs, Z. J., Audretsch, D.B. and Lehmann, E.E. (2013), "The knowledge spillover theory of entrepreneurship", Small Business Economics, Vol. 41 No. 4, pp. 757-774.

Acosta, M., Coronado, D. and Flores, E. (2011), "University spillovers and new business location in high-technology sectors: Spanish evidence", Small Business Economics Vol. 36 No. 3, pp. 365-376.

Algieri, B., Aquino, A. and Succurro, M. (2013), "Technology transfer offices and academic spin-off creation: the case of Italy", The Journal of Technology Transfer, Vol. 38 No.4, pp. $382-400$. 
Alto, P. and Farny, S. (2016), "Entrepreneurial Aalto: Where science and art meet technology and business", in Foss, L. and Gibson, D.V. (Eds), The Entrepreneurial University: Context and Institutional Change, Routledge, pp.150-166.

Argyris, C. and Schon, D. (1978), "Organizational Learning: A Theory in Action Perspective, Addison-Wesley, Reading, MA.

Armstrong, S. and Wilkinson, A. (2007), "Processes, procedures and journal development: past, present and future", International Journal of Management Reviews, Vol. 9, pp. 81-93. Audretsch, D. B., Keilbach, M.C. and Lehmann, E.E. (2006), "Entrepreneurship and economic growth". Oxford University Press.

Audretsch, D.B., Hülsbeck, M. and Lehmann, E.E. (2012), "Regional competitiveness, university spillovers, and entrepreneurial activity", Small Business Economics, Vol. 39 No. 3, pp. 587-601.

Audretsch D.B. and Belitski M. (2013), "The missing pillar: The creativity theory of knowledge spillover entrepreneurship", Small Business Economics, pp. 1-18.

Audretsch D.B. and Caiazza R. (2016), "Technology transfer and entrepreneurship: Crossnational analysis", The Journal of Technology Transfer, Vol. 41 No. 6, doi 10.1007/s10961015-9441-8

Autio, E., Kenney, M., Mustar, P., Siegel, D. and Wright, M. (2014), "Entrepreneurial innovation ecosystems and context", Research Policy, Vol. 43 No.7, pp. 1097-1108.

Azagra-Caro, J.M., Archontakis, F., Gutierrez-Gracia, A. and Fern'andez-de-Lucio, F. (2006), "Faculty support for the objectives of university-industry relations versus degree of R\&D cooperation: The importance of regional absorptive capacity", Research Policy, Vol. 35, pp. 37-55.

Bandura, A. (1986), "Social Foundations of Thought and Action", Englewood Cliffs, NJ: Prentice-Hall.

BIS (2015) Fulfilling our Potential: Teaching Excellence, Social Mobility and Student Choice, November 2015. Available at:

https://www.gov.uk/government/uploads/system/uploads/attachment_data/file/474227/BIS15-623-fulfilling-our-potential-teaching-excellence-social-mobility-and-student-choice.pdf BIS (2014) Funding per student in higher education. Available at:

https://www.gov.uk/government/uploads/system/uploads/attachment_data/file/318628/BIS_p erformance_indicators_Funding_per_student_in_HE.pdf

Bonaccorsi, A., Colombo, M.G., Guerini, M. and Rossi-Lamastra, C. (2013), "University specialization and new firm creation across industries", Small Business Economics, Vol. 41 No. 4, pp. 837-863.

Caiazza, R., Audretsch, D., Volpe, T. and Debra Singer, J. (2014), "Policy and institutions facilitating entrepreneurial spin-offs: USA, Asia and Europe", Journal of Entrepreneurship and Public Policy, Vol. 3 No. 2, pp. 186-196.

Caiazza, R., Richardson, A. and Audretsch, D. (2015), "Knowledge effects on competitiveness: From firms to regional advantage", The Journal of Technology Transfer, Vol. 40 No. 6, pp. 899-909.

Caiazza, R. and Audretsch, D. (2013), "A General Framework for Classifying SpinOffs", International Review of Entrepreneurship, Vol. 11 No. 1.

Caiazza, R. and Volpe T. (2016), "Innovation and its diffusion: Process, Actors and Actions", Technology Analysis \& Strategic Management, ISSN 0953-7325.

Caiazza, R. (2016), "A cross-national analysis of policies effecting innovation diffusion", The Journal of Technology Transfer, Vol. 41 No. 6, doi 10.1007/s10961-015-9439-2

Chinni, D. and Gimpel, J. (2011), "Our patchwork nation: The surprising truth about the 'real' America”. New York, NY: Gotham Books. 
Clarysse, B. and Moray, N. (2004), "A process study of entrepreneurial team formation: the case of a research-based spin-off”, Journal of Business Venturing, Vol. 19 No. 1, pp. 55-79.

Etzkowitz, H. and Leydesdorff, L. (2000), "The dynamics of innovation: from National Systems and "Mode 2" to a Triple Helix of university-industry-government relations". Research policy, Vol. 29 No. 2, pp.109-123.

Ewalt, D. (2015), “The World's Most Innovative Universities”. Reuters.

Fernald, L., Solomon, G. and El Tarabishy, A. (2005), "A New Paradigm: Entrepreneurial leadership". Southern Business Review, Vol. 30 No. 2, pp. 1-10.

Fetters, M., Greene, P., Rice, M. and Butler, J. (2010), "The Development of University-Based Entrepreneurship Ecosystems: Global Practices". Northhampton, MA: Edward Elgar Publishing.

Fiet, J. O. (2001a),"The theoretical side of teaching entrepreneurship", Journal of Business Venturing, Vol. 16 No. 1, pp. 1-24.

Fiet, J. O. (2001b), "The pedagogical side of entrepreneurship theory", Journal of Business Venturing, Vol. 16 No. 2, pp. 101-117.

Financial Times (2016), "University of Oxford receives backing for $£ 300 \mathrm{~m}$ science venture". Available at: http://www.ft.com/cms/s/0/b93fe688-f971-11e4-ae6500144feab7de.html\#axzz46SivBuVZ

Fini, R., Grimaldi, R., Santoni S. and Sobrero, M. (2011), "Complements Or Substitutes? The Role Of Universities And Local Context In Supporting The Creation Of Academic Spin-Offs". Research Policy, Vol. 40 No. 8, pp. 1113-1127.

Gibb, A. (2002), 'In pursuit of new 'enterprise' and 'entrepreneurship' paradigm for learning: creative destruction, new values, new ways of doing things and new combinations of knowledge", International Journal of Management Reviews, Vol. 4 No. 3, pp. 233-269.

Giunta, A., Pericoli, F. and Pierucci, E. (2016), "University-Industry collaboration in the biopharmaceuticals: the Italian case", Journal of Technology Transfer, Vol. 41, pp. 818-840. Hart, C. (1998), "Doing a Literature Review: Releasing the Social Science Research Imagination". Sage.

Hayter, C.S. (2013), "Conceptualizing knowledge-based entrepreneurship networks: Perspectives from the literature", Small Business Economics, Vol. 41 No. 4, pp. 899-911. Isenberg D.J. (2010), "How to start an entrepreneurial revolution", Harvard Business Review Vol. 88, pp. 41-49.

Lee, Y.S. (1996), "Technology transfer and the research university: a search for the boundaries of university-industry collaboration", Research Policy, Vol. 25, pp. 843-863.

Lockett, A., Wright, M. and Franklin, S. (2003), "Technology Transfer And Universities' Spinout Strategies". Small Business Economics, Vol. 20 No.2, pp. 185-200.

Markuerkiaga, L., Caiazza, R., Igartua, J. I. and Errasti, N. (2016), "Factors fostering students' spin-off firm formation: an empirical comparative study of universities from North and South Europe", Journal of Management Development, Vol. 35 No. 6, ISSN 0262-1711 Markman, G.D., Phan, P.H., Balkin, D.B. and Gianiodis, P.T. (2005), "Entrepreneurship and university-based technology transfer", Journal of Business Venturing, Vol. 20, pp. 241-263 Mason, C. and Brown, R. (2014), "Entrepreneurial Ecosystems and Growth Oriented Entrepreneurship". OECD LEED Programme and the Dutch Ministry of Economic Affairs.

Matheson, R. (2015), "New report outlines MIT's global entrepreneurial impact". MIT News, December, 9, 2015. Available at: http://news.mit.edu/2015/report-entrepreneurial-impact1209.

Mueller, P. (2006), "Exploring the knowledge filter: How entrepreneurship and universityindustry relationships drive economic growth", Research Policy, Vol. 35 No. 10, pp. 14991508. 
Mulrow, C. D. (1994), "Rationale for systematic reviews", British Medical Journal, Vol. 309, pp. 597.

Mustar, P., Renault, M., Colombo, M.G., Piva, E., Fontes, M., Lockett, A., Wright, M., Clarysse, B. and Moray, N. (2006), "Conceptualizing The Heterogeneity Of Research-Based Spin-Offs: A Multi-Dimensional Taxonomy”, Research Policy, Vol. 35 No. 2, pp. 289-308.

Neck, H. M. and Greene, P.G. (2011), "Entrepreneurship education: known worlds and new frontiers", Journal of Small Business Management, Vol. 49 No. 1, pp. 55-70.

Neck, H. M., Greene, P. G. and Brush, C.G. (2014). "Teaching entrepreneurship: A practicebased approach". Edward Elgar Publishing.

Owen-Smith, J. and Powell, W.W. (2004), "Knowledge networks as channels and conduits:

The effects of spillovers in the Boston biotechnology community". Organization Science, Vol. 15 No. 1, pp. 5-21.

Pirnay, F., Surlemont, B. and Nlemvo, F. (2003), "Toward A Typology Of University SpinOffs", Small Business Economics, Vol. 21 No. 4, pp. 355-369.

Pittaway, L. and Cope, J. (2007), "Simulating entrepreneurial learning: integrating experiential and collaborative approaches to learning", Management Learning, Vol. 38 No. 2, pp. 211-233. Powell, J. and Houghton, J. (2008), "Action learning as a core process for SME business support Action Learning", Research and Practice, Vol. 5 No. 2, pp. 173-184.

Szerb, L., Acs, Z., Autio, E., Ortega-Argiles, R., Komlosi, E. et. al. (2013), "REDI: The

Regional Entrepreneurship and Development Index - Measuring regional entrepreneurship".

European commission: Final Report.

Taylor, D.W. and Thorpe, R. (2004), "Entrepreneurial learning: a process of co-participation", Journal of Small Business and Enterprise Development, Vol. 11 No. 2, pp. 203-211.

Tether, B.S. and Tajar, A. (2008), "Beyond industry-university links: Sourcing knowledge for innovation from consultants, private research organisations and the public science-base". Research Policy, Vol. 37 No. 6-7, pp. 1079-1095.

Times Higher Education (2015), "Let students build tech products, UK sector told". Available at: https://www.timeshighereducation.com/news/let-students-build-tech-products-uk-sectortold

Times Higher Education (2016). "The world's top universities for attracting industry funding”. Available at:

https://www.timeshighereducation.com/world-university-rankings/funding-for-innovationranking-2016

Tranfield, D., Denyer, D. and Smart, P. (2003), "Towards a methodology for developing evidence-informed management knowledge by means of systematic review", British Journal of Management, Vol. 14, pp. 207-222.

Wright, M., Clarysse, B., Lockett, A. and Binks, M. (2006), "Venture Capital And University Spin-Outs". Research Policy, Vol. 35 No. 4, pp. 481-501. 
Appendix A. List of papers (excluding book chapters) from each journal included in this literature review and in the paper

\begin{tabular}{|l|c|c|}
\hline & $\begin{array}{l}\text { papers in } \\
\text { the review }\end{array}$ & $\begin{array}{l}\text { papers finally } \\
\text { selected }\end{array}$ \\
\hline Bournal title & 1 & 1 \\
\hline British Medical Journal & 3 & 1 \\
\hline Entrepreneurnal of Management & 3 & 0 \\
\hline Harvard Business Review & 3 & 1 \\
\hline International Journal of Management Reviews & 2 & 1 \\
\hline International Journal of Management Reviews & 3 & 1 \\
\hline International Review of Entrepreneurship & 2 & 1 \\
\hline Management Learning & 2 & 1 \\
\hline Journal of Business Venturing & 8 & 5 \\
\hline Journal of Small Business and Enterprise Development & 3 & 1 \\
\hline Journal of Technology Transfer & 4 & 2 \\
\hline Journal of Small Business Management & 2 & 1 \\
\hline Journal of Entrepreneurship and Public Policy & 1 & 1 \\
\hline Journal of Management Development & 2 & 0 \\
\hline Organization Science & 2 & 1 \\
\hline Research and Practice & 1 & 1 \\
\hline Research Policy & 14 & 9 \\
\hline Regional studies & 2 & 0 \\
\hline Southern Business Review & 2 & 1 \\
\hline Small Business Economics & 12 & 8 \\
\hline Strategic Management Journal & 3 & 0 \\
\hline Strategic Entrepreneurship Journal & 5 & 0 \\
\hline Total & 80 & 37 \\
\hline
\end{tabular}

